\title{
Zagrożenia pyłem i ich zwalczanie w zakładach przeróbki mechanicznej kopalń węgla kamiennego
}

\author{
Aleksander LUTYŃSKI ${ }^{1)}$
}

\footnotetext{
1) Prof. dr hab. inż.; Instytut Techniki Górniczej KOMAG; email: aleksander.lutynski@wp.pl, alutynski@komag.eu, tel. 603517726
}

http://doi.org/10.29227/IM-2021-01-02

Submission date: 14-01-2021 | Review date: 18-05-2021

Abstrakt
W opracowaniu opisano zagadnienia związane ze zwalczaniem najistotniejszych zagrożenia pyłem węglowym, które występuje wa-
kładach przeróbki mechanicznej wegla kamiennego. Przedstawiono problemy występowania zagrożenia wybuchem pyłu węglowego
podając źródła jego powstawania i prezentując dwuletnią statystykę występowania stref zagrożenia tym wybuchem wolskich orga-
nizacjach węglowych skupiajacych różne kopalnie. W opracowaniu zaprezentowano również problemy zagrożenia zdrowia pyłem
węglowym w zakładach przeróbki. Podano sposób identyfikacji tego zagrożenia oraz trzyletnią statystykę stanowisk pracy zagrożo-
nych obecnościa pyłu weglowego stanowiacego zagrożenie dla zdrowia. Statystyka ta dotyczy liczby stanowisk, na których stwierdza
się przekroczenie najwyższych dopuszczalnych stężén pyłu i stanowisk, na których stężenie pyłu węglowego zawiera się w granicach
0,5 do 1 NDS. Przedstawiono również metody techniczne zwalczania zagrożén pyłem weglowym. Opisano także rozwiazania urza-
dzeń odpylających na mokro i sucho, będące efektem prac Instytutu Techniki Górniczej KOMAG. Podano też podstawowe akty praw-
ne odnoszace się do zwalczania zagrożén pyłem węglowym.

Keywords: wegiel kamienny, przeróbka mechaniczna, zagrożenie pyłem

\section{Wprowadzenie}

Zagrożenie pyłem występujące w zakładach górnictwa węgla kamiennego jest jednym z najistotniejszych i najbardziej niebezpiecznych. Źródłem powstawania pyłu w atmosferze stanowisk pracy są niemal wszystkie operacje technologiczne procesu pozyskiwania węgla od urabiania calizny węglowej i skał towarzyszących po załadunek wzbogaconego surowca na środki transportujące go do odbiorcy czy deponowanie na zwałach.

Powstawanie pyłu w zakładach przeróbki mechanicznej kopalni warunkowane jest szeregiem czynników, do których zaliczyć należy:

- $\quad$ właściwości samego węgla oraz skał towarzyszących (stopień uwęglenia, zawartość wilgoci, skład mineralny, itp.),

- $\quad$ sposób eksploatacji pokładu węglowego, zastosowane metody i maszyny urabiające caliznę węglową,

- $\quad$ sposób załadunku na środki transportu i rodzaj tych środków,

- przyjęte technologie wzbogacania surowca oraz zastosowane maszyny i urządzenia w układzie technologicznym zakładu przeróbczego.

Za maszyny i urządzenia mające najistotniejszy wpływ na generowanie pyłów zakładzie przeróbczym uznawane są wywroty, taśmowe przenośniki przebiercze, urządzenia transportujące urobek i produkty wzbogacania, kruszarki, przesiewacze klasyfikujące, podajniki wibracyjne, przesypy, zsuwnie i zsypnie.

Szacuje się, że podczas urabiania, transportu i przeróbki od $1 \%$ do $3 \%$ urobku zamienia się w pył kamienno-węglowy, z czego około 30\% tego pyłu powstaje w procesach przeróbki węgla.

Pył występujący w zakładach przeróbki mechanicznej kopalń węgla kamiennego generuje dwa odmienne w swojej istocie zagrożenia. Są nimi:

- zagrożenie wybuchem,
- $\quad$ zagrożenie pyłem będącym czynnikiem szkodliwym dla zdrowia i uciążliwym.

Zagrożenie pyłem identyfikuje się mając za podstawę istniejące i obowiązujące akty prawne szeroko opisane $\mathrm{w}$ [14] Pomiary stężenia pyłu w atmosferze wokół stanowisk pracy wykonuje się zgodnie z normą [18]. Badania zawartości pyłu i oznaczanie pyłu całkowitego na stanowiskach pracy wykonywane są metodą filtracyjno-wagową w oparciu o normę [19]. Metody pomiaru stężenia pyłu w atmosferze są doskonalone i dąży się w nich do opracowania aparatury pozwalającej na prowadzenia pomiarów ciągłych [16].

Przepisy zawarte w Rozporządzeniu Ministra Gospodarki z 28 czerwca 2002 r. [29] wymagają aby:

- oznaczenia stężenia pyłu w powietrzu, na stanowisku pracy, dokonywane były na podstawie uzyskanych wyników z serii pobranych próbek pyłu generowanego $\mathrm{w}$ procesie technologicznym,

- czas pobierania poszczególnych próbek pyłu był tak ustalany, aby masa pyłów osadzonych na filtrze nie przekroczyła maksymalnej wartości określonej dla danego typu przyrządu pomiarowego, a łączny czas pobierania próbek nie był krótszy, niż ustalony czas trwania zmiany roboczej i powinien obejmować co najmniej 70\% czasu trwania procesu technologicznego,

- próbki pyłu, do oznaczania stężeń pyłu w powietrzu na poszczególnych stanowiskach pracy, pobierane były podczas wszystkich czynności procesu technologicznego,

- pomiary na stanowiskach pracy wykonywane były nie później niż 7 dni:

- po oddaniu do ruchu nowego obiektu lub urządzenia,

- $\quad$ przy pracach, w których może nastąpić zapylenie powietrza, 
Tab. 1. Strefy zagrożeń wybuchem pyłu węglowego w zakładach przeróbki mechanicznej kopalń węgla kamiennego [27,28]

Tab. 1. Coal dust hazard zones in mechanical processing plants of hard coal mines $[27,28]$

\begin{tabular}{|c|c|c|c|c|c|c|}
\hline \multirow[t]{2}{*}{ Organizacja } & \multicolumn{3}{|c|}{$\begin{array}{l}\text { Liczba stref zagrożonych } \\
\text { wybuchem pyłu } 2018 \text { rok }\end{array}$} & \multicolumn{3}{|c|}{$\begin{array}{l}\text { Liczba stref zagrożonych } \\
\text { wybuchem pyłu } 2019 \text { rok }\end{array}$} \\
\hline & 20 & 21 & 22 & 20 & 21 & 22 \\
\hline PG SA & 0 & 0 & 137 & 0 & 0 & 133 \\
\hline JSW SA & 1 & 1 & 38 & 1 & 1 & 37 \\
\hline Tauron Wydobycie SA & 0 & 0 & 3 & 0 & 0 & 3 \\
\hline Węglokoks Kraj SA & 0 & 0 & 13 & 0 & 0 & 6 \\
\hline Kopalnie samodzielne & 16 & 16 & 0 & 16 & 16 & 0 \\
\hline Suma & 17 & 17 & 191 & 17 & 17 & 179 \\
\hline
\end{tabular}

- po wprowadzeniu zmian technologicznych,

- $\quad$ wystąpieniu zaburzeń i zmian geologicznych powodujących zmiany w stężeniu pyłu w powietrzu.

Zwrócić należy uwagę na niezwykle istotny problem, jakim jest osiadanie pyłu na elementach konstrukcji stanowiących zabudowę zakładu, maszynach oraz urządzeniach, które znajdują się w pobliżu miejsc generujących powstawanie pyłu. Pył ten wskutek podmuchów powietrza może zostać uniesiony i tym samym stworzyć realne zagrożenie powstania mieszanki wybuchowej.

Pomiar intensywności osiadania pyłu węglowego wykonywany jest na podstawie przedmiotowej normy [20].

Wobec zagrożeń pyłowych występujących w zakładzie przeróbczym węgla podejmowane są działania mające na celu ich ograniczenie lub wręcz likwidację. Są to zarówno metody techniczne jak i organizacyjne oraz administracyjno-prawne, takie jak normy, dyrektywy, rozporządzenia prowadzące do tworzenia systemów zarzadzania bezpieczeństwem $[10,11,12,15,19]$ i instrukcji celowanych.

\section{Zagrożenie wybuchem pyłu w zakładach przeróbki}

Wybuch pyłu to egzotermiczna reakcji chemiczna, która przebiega w bardzo krótkim czasie. Wynikiem tej reakcji jest powstawanie znacznej ilości gazów. Pył węglowy w ilości od 50 do $1000 \mathrm{~g} / \mathrm{m}^{3}$, zawierający powyżej 10\% części lotnych, zawieszony w powietrzu stanowi mieszankę, która w wyniku inicjacji termicznej może doprowadzić do wybuchu. Należy nadmienić, że aktualnie wszystkie eksploatowane w polskich kopalniach pokłady zawierają powyżej 10\% części lotnych w bezwodnej i bezpopiołowej substancji węglowej.

Intensywność występowania pyłu węglowego w zakładzie przeróbki mechanicznej kopalni jest zróżnicowana i zależy od czynności wykonywanych w poszczególnych sekcjach i stanowiskach układu technologicznego. Najwyższy poziom zapylenia identyfikowany jest $\mathrm{w}$ przestrzeni sekcji z procesami prowadzonymi „na sucho”. Zaliczyć należy sekcje: klasyfikacji, rozdrabniania grubych sortymentów, suszenia koncentratów mułowych, sortowania i załadunku produktów handlowych. Ponadto pył generowany jest na przesypach układów transportujących urobek między sekcjami technologicznymi i zasypach zbiorników. Również możliwym miejscem powstawania zawieszonego w powietrzu pyłu węglowego są też zwały węgla.

Minimalne wymagania odnoszące się do bezpieczeństwa i higieny pracy i związane z oceną ryzyka wystąpienia atmosfery wybuchowej w miejscu pracy podane zostały Rozporządze- niu Ministra Gospodarki z dnia 8 lipca 2010 r. [31]. Ocena ta jest podstawą podziału przestrzeni, które zagrożone są wybuchem na trzy strefy. W odniesieniu do pyłu węglowego strefy te oznaczane są odpowiednio jako:

- $\quad$ strefa 20 - jako przestrzeń w której atmosfera wybuchowa w postaci palnego pyłu w powietrzu występuje stale, często lub przez długie okresy,

- $\quad$ strefa 21 - jako przestrzeń, w której atmosfera wybuchowa w postaci palnego pyłu w powietrzu może czasami wystąpić $\mathrm{w}$ trakcie normalnego działania,

- $\quad$ strefa 22 - jako przestrzeń, w której atmosfera wybuchowa w postaci palnego pyłu w powietrzu nie występuje $\mathrm{w}$ trakcie działania, a w przypadku wystąpienia utrzymuje się przez krótki okres.

Prowadzone od szeregu lat okresowe analizy zagrożenia wybuchem pyłu węglowego w zakładach przeróbki mechanicznej kopalń węgla kamiennego wykazują tendencję spadkową liczby stref o tym zagrożeniu. W zdecydowanej większości zakładów przeróbczych nie występują strefy 20 i 21 . Natomiast atmosfera wybuchowa w postaci palnego pyłu w powietrzu nie występuje, a w przypadku jej wystąpienia utrzymuje się przez krótki okres czasu. Jak łatwo zauważyć w ostatnich dwóch latach nastąpił nieznaczny spadek wystąpienia zagrożenia wybuchem pyłu w strefach 22 .

Ilustracją tego stwierdzenia są wyniki analiz zaprezentowane w Tabeli $1[27,28]$.

\section{Zagrożenie pyłem jako czynnikiem szkodliwym dla zdrowia i uciążliwym}

Pył węglowy powstający w procesach pozyskiwania surowca, jak wspomniano powyżej, stwarza zagrożenie wybuchem i jest także szkodliwy dla zdrowia oraz uciążliwy. Jest on drobno uziarniony i w swoim składzie zawiera wolną krzemionkę. Z uwagi na skutki zdrowotne najistotniejsze w nim są cząstki posiadające średnicę poniżej $7 \mu \mathrm{m}$. Umożliwia to bowiem ich przeniknięcie do stref wymiany gazowej w płucach. Skutkiem długotrwałego przebywania $\mathrm{w}$ atmosferze $\mathrm{z}$ pyłem jest przewlekła choroba układu oddechowego - pylica płuc. Może być ona przyczyną szeregu chorób takich jak przewlekłe zapalenie oskrzeli, rozedma płuc, niewydolność układu oddechowego i układu krążenia, nadciśnienie płucne, zespół tak zwanego serca płucnego, czyli przerost mięśnia prawej komory serca, duszność, kaszel, ból w klatce piersiowej.

Rodzaj choroby jaką wywołuje pył oddziałujący na układ oddechowy zależy od rodzaju pyłu wdychalnego, a zagrożenie 
Tab. 2. Najwyższe dopuszczalne rozporządzeniem stężenia pyłu węglowego (NDS) na stanowiskach pracy, $\mathrm{mg} / \mathrm{m}^{3}$ [29] Tab. 2. Highest allowable concentration of coal dust (NDS) in work places, $\mathrm{mg} / \mathrm{m}^{3}$ [29]

\begin{tabular}{|c|c|c|c|c|}
\hline \multirow{2}{*}{ Frakcja pyłu } & \multicolumn{5}{|c|}{ Zawartość krzemionki w pyle, \% } \\
\cline { 2 - 5 } & $<2$ & od 2 do 10 & od 10 do 50 & $>50$ \\
\hline Wdychalna & 10 & 4 & 2 & 2 \\
\hline Respirabilna & - & 2 & 1 & 0,3 \\
\hline
\end{tabular}

Tab. 3. Liczby stanowisk w zakładach przeróbczych zagrożone występowaniem pyłów [27,28]

Tab. 3. Number of work places with potential coal dust hazard [27,28]

\begin{tabular}{|l|c|c|c|c}
\hline \multirow{2}{*}{ Organizacja } & \multicolumn{2}{|c|}{$\begin{array}{c}\text { Liczba stanowisk zagrożonych } \\
\text { występowaniem pyłów } \\
\text { 2018 rok }\end{array}$} & \multicolumn{2}{c}{$\begin{array}{c}\text { Liczba stanowisk zagrożonych } \\
\text { występowaniem pyłów 2019 } \\
\text { rok }\end{array}$} \\
\cline { 2 - 5 } & $>$ NDS & $0,5-1$ NDS & $>$ NDS & $0,5-1$ NDS \\
\hline PG SA & 143 & 329 & 125 & 264 \\
\hline JSW SA & 81 & 153 & 81 & 128 \\
\hline Tauron Wydobycie SA & 20 & 47 & 20 & 55 \\
\hline Węglokoks Kraj SA & 42 & 25 & 17 & 33 \\
\hline Kopalnie samodzielne & 29 & 31 & 22 & 37 \\
\hline & 315 & 585 & 165 & 517 \\
\hline
\end{tabular}

jakie on stwarza zależy od stopnia jego stężenia. Cząstki pyłów zawierających wolną krystaliczną krzemionkę mogą wywoływać krzemicę.

Jak wynika z badań prowadzonych przez Instytut Medycyny Pracy - Państwowy Instytut Badawczy, pylica płuc jest najczęściej występującą chorobą zawodową górników. Wyniki tych badań pokazały, że w latach 2014-2018 w całym górnictwie stwierdzono łącznie 1855 przypadków chorób zawodowych. Zachorowania na pylicę płuc kształtują się na poziomie $86,6 \%$ analizowanych chorób zawodowych. W analizowanym okresie pylicę wykryto u 1607 górników [32].

Najwyższych dopuszczalnych stężeń szkodliwych dla zdrowia w środowisku pracy (NDS), w tym i pyłu, dotyczy Rozporządzenie Ministra Pracy i Polityki Społecznej z dnia 29 czerwca 2014 r (Dz.U. poz. 817) [29]. W rozporządzeniu tym stwierdza się, że najwyższe dopuszczalne stężenie (NDS) jest średnią stężenia ważonego, którego oddziaływanie na pracownika w ciągu dobowego 8-godzinnego i tygodniowego czasu pracy przez okres jego aktywności zawodowej. Oddziaływanie to nie powinno powodować niekorzystnych zmian w jego stanie zdrowia jak i w stanie zdrowia jego przyszłych pokoleń. Celem ustalania NDS szkodliwych dla zdrowia jest zminimalizowanie ich stężenia $\mathrm{w}$ środowisku pracy do poziomu, który jest akceptowalny z punktu widzenia ryzyka zdrowotnego. Rozporządzenie podaje dopuszczalne stężenia pyłu węglowego, które zależą od ilości krzemionki w nim zawartej. Wartości najwyższych dopuszczalnych stężeń pyłu podano w tabeli 2.

Niezwykle ważnymi w identyfikacji zawartości pyłu kopalnianego w atmosferze oraz jego szkodliwości są badania przeprowadzane metodami podanymi w przedmiotowych normach $[21,22,23,24,25,26]$. Częstotliwość wykonywania tych badań określono w Rozporządzenie Ministra Zdrowia dnia 20 kwietnia 2005 r. (Dz.U. nr 73, poz. 645 wraz ze zmianami) [30]. Pracodawca jest zobowiązany powiadomić pracowników o uzyskanych wynikach badań oraz umieszczać je na odpowiednim stanowisku pracy. Ponadto wyniki te wpisywane są w wymaganą rozporządzeniem kartę badań i archiwizowane przez okres trzech lat.
W kopalniach do pobierania próbek powietrza stosowany jest powszechnie pyłomierz grawitacyjny CIP-10.

Badania zagrożenia pyłem $\mathrm{w}$ środowisku pracy wykonane w zakładach przeróbki mechanicznej wykazały, że prawie we wszystkich zakładach są stanowiska pracy, na których przekraczane są dopuszczalne przepisami wartości NDS [27,28]. Liczby stanowisk zagrożonych obecnością pyłów w okresie dwóch lat w poszczególnych organizacjach podane zostały w tabeli 3.

Przedstawione wyniki dwóch lat wskazują na spadek liczby stanowisk pracy w zakładach przeróbczych zagrożonych występowaniem w atmosferze pyłu węglowego. Spadek ten, w odniesieniu do najwyższego dopuszczalnego stężenia, wynosi niemal pięćdziesiąt procent.

\section{Metody techniczne zwalczania zagrożeń wywołanych pyłem}

Zagrożenia pyłem w zakładach przeróbczych, jak stwierdzono powyżej, zwalcza się wykorzystując metody organizacyjne i administracyjno-prawne oraz metody techniczne. Wieloletnia praktyka wykazała, że skutecznymi metodami technicznymi w zwalczaniu zagrożenia pyłem jest odpylanie lub zraszanie miejsc powstawania tego pyłu.

Odpylacze, będące urządzeniami odpylającymi na sucho lub na mokro, mają za zadanie wychwycenie pyłu węglowego powstającego w technologicznych procesach przeróbczych i transportowych.

O skuteczności rozwiązań odpylaczy świadczyć mogą wyniki przeprowadzonych badań i pomiarów w warunkach przemysłowych. Przykładem mogą być badania odpylacza przewałowego typu MB-M-25A odpylającego na mokro, które wykonane zostały w jednym z zakładów przeróbki mechanicznej kopalni węgla kamiennego, co opisano między innymi w [15]. W zakładzie tym w rejonach miejsc, w których powstaje pył węglowy, zamontowano wyciągi mające wychwycić i odprowadzić ten pył do centralnego odpylacza. Wyniki badań wskazały na kilkudziesięcio procentowe spadki ilości pyłu kopalnianego osiadającego wokół badanych stanowisk[15]. 
Tab. 4. Stężenia pyłu wdychalnego i respirabilnego na poszczególnych stanowiskach układu technologicznego w zakładzie przeróbki przy działającym i wyłączonym systemie zraszającym [8]

Tab. 4. Inhalable and respirable dust concentrations at individual work places of the technological system in the processing plant with the spraying system working and switched off [8]

\begin{tabular}{|c|c|c|c|c|}
\hline $\begin{array}{c}\text { Stanowisko } \\
\text { pracy }\end{array}$ & Typ frakcji pyłu & $\begin{array}{c}\text { Stężenie pyłu - } \\
\text { instalacja } \\
\text { wyłączona, } \\
\mathrm{mg} / \mathrm{m}^{3}\end{array}$ & $\begin{array}{c}\text { Stężenie pyłu - } \\
\text { instalacja } \\
\text { włączona, } \mathbf{m g} / \mathrm{m}^{3}\end{array}$ & $\begin{array}{c}\text { Skuteczność redukcji } \\
\text { stężenia pyłu, } \\
\%\end{array}$ \\
\hline \multirow{2}{*}{1} & wdychalna & 11,88 & 5,92 & 50 \\
\hline & respirabilna & 2,02 & 1,20 & 40 \\
\hline \multirow{2}{*}{2} & wdychalna & 5,42 & 2,36 & 57 \\
\hline & respirabilna & 2,06 & 0,52 & 75 \\
\hline \multirow{2}{*}{3} & wdychalna & 3,12 & 1,16 & 63 \\
\hline & respirabilna & 0,57 & 0,21 & 62 \\
\hline \multirow{2}{*}{4} & wdychalna & 5,46 & 1,47 & 73 \\
\hline & respirabilna & 0,91 & 0,12 & 86 \\
\hline \multirow{2}{*}{5} & wdychalna & 3,98 & 1,91 & 52 \\
\hline & respirabilna & 1,35 & 0,67 & 51 \\
\hline
\end{tabular}

Interesującym w budowie i zasadach działania są mokre urządzenia odpylające, które powstały w Instytucie Techniki Górniczej KOMAG [1,2,3,4,5,6]. Pozwalają one na stosowanie w różnych miejscach zakładu górniczego, wszędzie tam gdzie pojawia się pył. Są to urządzenia:

- $\quad$ typu UO, w których woda jest rozpraszana dyszami stałymi lub dyszą wirową. Skuteczności ich odpylania dochodzi do $99,7 \%$.

- typu DCU działające na zasadzie kontaktu strugi zanieczyszczonego pyłem powietrza z kurtyną wodną.

- typu LDCU, w których połączono mokre odpylanie z labiryntowym przepływem powietrza. Urządzenie to może pracować w systemach wentylacji ssącej oraz kombinowanej.

- typu DRU, w których połączono tradycyjny natrysk wody z silną separacją odśrodkową. Ten typ urządzenia charakteryzuje się wysoką skutecznością odpylania przy stosunkowo niskich oporach przepływu.

Rozwiązaniem konstrukcyjnym o innym sposobie działania jest urządzenie odpylające na sucho $\mathrm{z}$ aktywnym układem tłumienia wybuchu. Zostało ono opracowane w ramach projektu rozwojowego finansowanego przez NCBR, który realizował Instytut Techniki Górniczej KOMAG wspólnie z Politechniką Warszawską [9]. Urządzenie to składa się z dwóch komór, w których znajdują się wkłady kasetowe osadzone na wspólnej ramie w metalowym koszu. Rama $\mathrm{z}$ wkładami kasetowymi jest połączona przesuwnie względem obudowy odpylacza. Jest ona wprawiana w ruch posuwisto zwrotny silnikiem elektrycznym i układem korbowodowym. Ruch ten powoduje strącanie pyłu, osadzającego się na tkaninie filtracyjnej, do zbiornika ulokowanego się w dole odpylacza. Podciśnienie w odpylaczu wytwarzane jest wentylatorem osiowym stanowiącym integralną część odpylacza. Odpylacz posiada aktywny system tłumienia wybuchu co pozwala na stosowanie go $\mathrm{w}$ przestrzeniach zagrożonych wybuchem pyłu oraz metanu.

Innym podejściem Instytutu Techniki Górniczej KOMAG w konstruowaniu urządzeń wykorzystywanych do zwalczania zagrożenia pyłowego są urządzenia zraszające wykorzystujące baterie dysz powietrzno-wodnych. Baterie te montowane są bezpośrednio w miejscach powstawania pyłu. Instalacje są zasilane wodą lub wodą ze sprężonym powietrzem, które wspomaga proces rozpylania kropel.
Jednym z rozwiązań, które zastosowano w zakładach przeróbczych, jest system mgłowy PASAT. Pierwsze urządzenie zraszające tego typu wdrożone zostało w Zakładzie Przeróbki Mechanicznej Polskiej Grupy Górniczej Sp. z o.o. KWK „Bolesław Śmiały" na przesypie z kruszarki. Kolejne urządzenia tego typu zainstalowane zostały w innych miejscach tego zakładu oraz w KWK „Mysłowice-Wesoła”. W kopalni tej na przesypach z przenośników stalowo-członowych na przenośniki taśmowe wdrożono także zmodyfikowany system PASAT-W.

Najnowszym rozwiązaniem zaprojektowanym przez ITG KOMAG, które ma na celu ograniczenie zagrożenia pyłem na stanowiskach pracy, jest system zraszania NEPTUN. System ten zastosowano w ZPMW Polskiej Grupy Górniczej Sp. z o.o. Oddział KWK „Bolesław Śmiały”. Wykonawcą była Firma Innowacyjno-Wdrożeniowa „Elektron”. Rozwiązanie to składa się $\mathrm{z}$ siedmiu niezależnych instalacji zraszających zabudowanych na pięciu stanowiskach [7] obsługi wskazanych przez służby kopalni. Były to:

- urządzenia załadowcze i rozładowcze zbiorników kamienia,

- urządzenia wzbogacające,

- urządzenia kruszące i transportujące,

- urządzenia załadowcze i rozładowcze zbiorników węgla,

- $\quad$ podajniki na poziomie $+3,70 \mathrm{~m}$.

W systemie zraszającym zastosowano specjalne atomizery ultradźwiękowe, które pozwalają na pracę w zakresie niskich wartości ciśnienia zarówno wody jak i sprężonego powietrza. Istotną zaletą systemu jest wytwarzanie strumienia zraszającego, który nie powoduje znaczącego zwiększenia zawilgocenia transportowanego materiału.

Po zamontowaniu systemu wykonano badania skuteczności jego działania porównując stężenia pyłu w atmosferze pięciu wymienionych stanowisk pracy przy działającym i wyłączonym systemie zraszającym [8]. Badania wykonywano przez cztery godziny dla każdego stanu pracy systemu.

Badania polegały na wyposażeniu osób pracujących na wymienionych stanowiskach zakładu w pyłomierze osobiste typu:

- CIP-10R do pomiaru frakcji respirabilnej pyłu,

- CIP-10I do pomiaru frakcji wdychalnej pyłu.

Pozyskane masy pyłu z miseczek pomiarowych zastosowanych pyłomierzy osobistych ważone były przez pracowni- 
ków Laboratorium Pomiarów Zapylenia Powietrza Głównego Instytutu Górnictwa w Katowicach, które jest jednostką akredytowaną w zakresie badań w środowisku pracy przez Polskie Centrum Akredytacji. Uzyskane wyniki pozwoliły na oceną skuteczności działania zastosowanych systemów zraszania w redukcji stężenia pyłu wdychalnego i respirabilnego generowanego w procesie technologicznym. Wyniki badań przedstawione są w tabeli 4.

Wyniki przeprowadzonych badań wskazują na dużą skuteczność systemów zraszających na poszczególnych stanowiskach układu technologicznego zakładu przeróbki węgla kopalni. W wyniki działania tych systemów stężenie frakcji wdychalnej pyłu zmniejszyło się na poszczególnych stanowiskach obsługi od 50 do $73 \%$, a frakcji respirabilnej od 40 do $85 \%$.

\section{Podsumowanie}

Opisane powyżej metody i środki zwalczania zagrożenia pyłem, który występuje na stanowiskach obsługi w zakładach przeróbki mechanicznej kopalń węgla kamiennego, wskazują na istotne możliwości skutecznej walki o ograniczenie czy wręcz eliminację tego zagrożenia. Szeroka paleta rozwiązań technologicznych i konstrukcyjnych pozwala na odpowiedni ich dobór do konkretnych warunków środowiskowych i lokalizacyjnych występujących w zakładzie przeróbczym.

W opracowaniu zaprezentowane zostały osiągnięcia Instytutu Techniki Górniczej KOMAG w tym zakresie. Urządzenia, których konstrukcję opracowano w tym Instytucie znalazły zastosowanie w wielu zakładach przeróbki mechanicznej kopalń węgla kamiennego, spełniając tym samym niezwykle istotną rolę w walce o stworzenie warunków pracy najkorzystniejszych i najbezpieczniejszych dla zdrowia i życia załóg górniczych.

\section{Literatura - References}

1. Babczyński J., Strączek K. (2015) Nowe rozwiązania w zakresie profilaktyki zwalczania zagrożenia pyłowego na przykładzie zakładu przeróbki mechanicznej węgla KWK Budryk. Inżynieria Górnicza 2015, nr 2-3

2. Bałaga D. i inni. (2013) Urządzenia zraszające od redukcji zapylenia w wyrobiskach chodnikowych z zastosowaniem mgły wodnej. Nowoczesne metody eksploatacji węgla i skał zwięzłych. Monografia, Akademia Górniczo-Hutnicza im. Stanisława Staszica, Kraków s. 97-106; 0,60 ark. wyd., ISBN 978-83-930353-1-1

3. Bałaga D. i inni (2015) Metody i środki zwalczania zagrożeń pyłowych i metanowych w górnictwie węglowym. Maszyny Górnicze nr 3

4. Bałaga D., Siegmund M.; Urbanek A. (2012) Nowe rozwiązania urządzeń zraszających ograniczające zagrożenia pyłowe w górnictwie. Maszyny Górnicze nr 2

5. Bałaga D., Siegmund M. (2015) Systemy do redukcji zapylenia w zakładach przeróbczych. Maszyny Górnicze nr $1 \mathrm{~s}$. 8-15, ISSN 0209-3693.

6. Jedziniak M. (2013) Małogabarytowe urządzenie odpylające. Maszyny Górnicze nr.4

7. Bałaga D., Kalita M., Siegmund M., Klimek Z., Urbanek A., Wałoszczyk A. (2018) Projekt instalacji zraszającej NEPTUN do zmniejszania zapylenia w zakładzie przeróbczym KWK "Bolesław Śmiały". Maszyny Górnicze nr 3 s. 35-46, ISSN 2450-9442

8. Bałaga D., Kalita M., Siegmund M., Klimek Z. (2019) Wyniki badań zapylenia na stanowiskach pracy zakładu przeróbczego kopalni węgla kamiennego po zabudowie systemu zraszania NEPTUN. NowyLewel.html. 17.11.2019

9. Bałaga D. i inni (2015) Metody i środki zwalczania zagrożeń pyłowych i metanowych w górnictwie węglowym. Maszyny Górnicze nr 3

10. Kapusta M., Bąk P., Sukiennik M.( 2019). The Impact of the Management System on Developing Occupational Safety Awareness Among Employees. Inżynieria Mineralna z. 2(44)

11. Kapusta M., Sukiennik M., Bąk P. (2018). Effectiveness of Occupational Health and Safety Rules in Shaping Organizational Culture. Inżynieria Mineralna z. 1(42)

12. Kowal B, Wiśniowski R., Ogrodnik R., Młynarczykowska A. (2019) : Selected Elements of a Safe Work Environment in Hard Coal Mines in the Polish Mining Sector. Inżynieria Mineralna z. 2(44)

13. Lutyński A. (2014) Ograniczenie zagrożeń pyłowych w zakładzie przeróbki mechanicznej kopalni węgla kamiennego. Rozdział w monografii: Mechanizacja, Automatyzacja i Robotyzacja w Górnictwie. Wydawnictwo CBiDGP ISBN 978-83-936657-7-8. Lędziny

14. Lutyński A. (2016) Zagrożenia metanem, pyłem i hałasem występujące w zakładach przeróbki mechanicznej kopalń węgla kamiennego. Instytut Techniki Górniczej KOMAG. Monografia nr.16. ISBN 978-83-60708- 96-5. Seria: Innowacyjne techniki i technologie mechanizacyjne. Gliwice. Stron 106 
15. Lutyński A. (2017) Zwalczanie zagrożeń wywołanych przez metan, pył i hałas w zakładach przeróbki mechanicznej kopalń węgla kamiennego. Instytut Techniki Górniczej KOMAG. Monografia ISBN 978-83-65593-03-0. Seria: Innowacyjne techniki i technologie mechanizacyjne. nr.18. Gliwice. Stron 126

16. Małachowski M. (2012) Wykorzystanie optycznej metody pomiaru stężenia pyłu do wspomagania oceny parametrów wpływających na możliwość zaistnienia wybuchu osiadłego pyłu węglowego Mechanizacja I Automatyzacja Górnictwa Nr 7(497)

17. Sukiennik M., Bąk P., Kapusta M. (2019). The Impact of the Management System on Developing Occupational Safety Awareness Among Employees. Inżynieria Mineralna z. 1(43)

18. PN-Z-04008-7:2002/Az1:2004 Pobieranie próbek powietrza w celu oceny narażenia na pyły, metale, substancje organiczne i nieorganiczne.

19. PN-91/Z-04030/05 Ochrona czystości powietrza. Badania zawartości pyłu. Oznaczanie pyłu całkowitego na stanowiskach pracy metodą filtracyjno-wagową.

20. PN-G-04036:1997 Zabezpieczenie przed wybuchem pyłu węglowego. Oznaczenie intensywności osiadania pyłu.

21. PN-EN 481:1998 Atmosfera miejsca pracy. Określenie składu ziarnowego dla pomiaru cząstek zawieszonych w powietrzu.

22. PN-91/Z-04030/05 Ochrona czystości powietrza. Badania zawartości pyłu. Oznaczanie pyłu całkowitego na stanowiskach pracy metodą filtracyjno-wagową.

23. PN-91/Z-04030/06 Ochrona czystości powietrza. Badania zawartości pyłu. Oznaczanie pyłu respirabilnego na stanowiskach pracy metodą filtracyjno-wagową.

24. PN-91/Z-04018/02 Ochrona czystości powietrza. Badania zawartości wolnej krystalicznej krzemionki. Oznaczanie wolnej krystalicznej krzemionki w pyle całkowitym na stanowiskach pracy metodą spektrometrii absorpcyjnej w podczerwieni.

25. PN-91/Z-04018/03 Ochrona czystości powietrza. Badania zawartości wolnej krystalicznej krzemionki. Oznaczanie wolnej krystalicznej krzemionki w pyle respirabilnym na stanowiskach pracy metodą spektrometrii absorpcyjnej w podczerwieni.

26. PN-91/Z-04018/04 Ochrona czystości powietrza. Badania zawartości wolnej krystalicznej krzemionki. Oznaczanie wolnej krystalicznej krzemionki w pyle całkowitym i respirabilnym w obecności krzemianów na stanowiskach pracy metodą kolorymetryczną

27. Raport roczny o stanie podstawowych zagrożeń naturalnych i technicznych w górnictwie węgla kamiennego w roku 2010. (2011) Główny Instytut Górnictwa Katowice.

28. Raport roczny o stanie podstawowych zagrożeń naturalnych i technicznych w górnictwie węgla kamiennego w roku 2011. (2012) Główny Instytut Górnictwa Katowice

29. Rozporządzenie Ministra Pracy i Polityki Socjalnej z dnia 29 czerwca 2014 r. w sprawie najwyższych dopuszczalnych stężeń i natężeń czynników szkodliwych dla zdrowia w środowisku pracy (Dz.U. poz. 817) wraz ze zmianami.

30. Rozporządzenie Ministra Zdrowia z dnia 20 kwietnia 2005 r. w sprawie badań i pomiarów czynników szkodliwych dla zdrowia w środowisku pracy (Dz.U. nr 73, poz. 645) wraz ze zmianami.

31. Rozporządzenie Ministra Gospodarki z dnia 8 lipca 2010r. w sprawie minimalnych wymagań dotyczących bezpieczeństwa i higieny pracy, związanych z możliwością wystąpienia atmosfery wybuchowej (Dz.U. nr 138 poz. 913)

32. https://everethnews.pl/newsy/pylica-pluc-najczestsza-choroba-zawodowa-gornikow/ (dostęp 19.04.2021)

Dust Hazards and their Control in Mechanical Processing Plants of Hard Coal Mines

The study describes issues related to the prevention of the risk of coal dust that occurs in hard coal mechanical processing plants. Dust explosion hazards in coal processing plants were described, including their origins, and a two-year statistics on the location of dust explosion zones in the Polish coal organization associating various mines.

The study presents also health hazard related to coal dust exposure in coal preparation plants. Methods of coal dust exposure identification and a two-year statistics of workplaces with exposure to coal dust hazard are presented. The statistics are related to workplaces where the coal dust concentration limits are exceeded and workplaces where the allowable exposure limit is between 0,5 and 1.

The technical methods of combating coal dust hazard are also presented.

Other dust prevention solutions such as dry and wet dust collectors developed by ITG KOMAG are described. In addition, basic regulations related to the coal dust prevention are listed.

Keywords: hard coal, mechanical processing, dust hazard 